\author{
MARTYNA ŁASZEWSKA-HELLRIEGEL \\ ORCID: 0000-0002-2212-371X \\ Uniwersytet Zielonogórski
}

\title{
ANALIZA WPROWADZANIA NAJNOWSZYCH ZMIAN W NIEMIECKIM PRAWIE TRANSPLANTACYJNYM - POLITYCZNE ASPEKTY DECYZJI SUMIENIA
}

\begin{abstract}
Abstrakt: Prawo jest uwikłane w politykę i jego kształt w znacznej mierze zależy nie tylko od istniejących potrzeb regulacji, lecz także od tego, jaką wizję wartości reprezentuje sprawujący władzę prawotwórczą parlament. Niniejszy artykuł przedstawia niedawną sytuację w polityce zdrowotnej Niemiec, gdzie poprzez zmianę zbioru norm ustawy transplantacyjnej zaproponowano zmianę całego sytemu postrzegania ludzkiego ciała. Co ciekawe, w tym wypadku projekt wprowadzający nowe prawo nie jest projektem koalicji rządzącej — mamy tu do czynienia z konkurencyjnymi projektami międzypartyjnymi. Gdy projekty ustawy proponują zmianę aksjologii norm prawnych zależną od sumienia, polityczność prawa przybiera inną od przeciętnej formę lub zupełnie znika. W tym tekście zostaną przedstawione polityczne aspekty projektu nowego prawa transplantacyjnego. Artykuł skupia się przede wszystkim na aspekcie dynamicznym polityczności prawa, czyli na procesie legislacyjnym i udziale w nim ekspertów, ale również na aspekcie epistemologicznym — jaki rodzaj i zakres materiałów badawczych został wykorzystany w procesie upolitycznienia prawa.
\end{abstract}

Słowa kluczowe: prawo transplantacyjne, decyzje sumienia, dawstwo organów, model zgody, model sprzeciwu

\section{WSTĘP}

Carl Schmitt w latach trzydziestych ubiegłego wieku jako pierwszy sformułował pojęcie „,polityczności”. W tamtych czasach myśl polityczna i prawnicza były skoncentrowane głównie na pytaniu o suwerena ${ }^{1}$. Suwerenem mógł być monarcha, lud, naród lub proletariat. Dla Hansa Kelsena natomiast suwerenem było samo prawo. Takie rozwiązanie było do zaakceptowania przez każdą siłę polityczną, gdyż pod tym pojęciem każda z nich będzie rozumiała coś innego. Z kolei

${ }^{1}$ M. Paździora, M. Stambulski, Co może dać nauce prawa polityczność? Przyczynek do przyszłych badań, „Archiwum Filozofii Prawa i Filozofii Społecznej” 2014, nr 1, s. 56; J. Zajadło, Prawoznawstwo - polityczność nauki czy nauka polityczności?, „Przegląd Prawa i Administracji” 110, 2017, s. 41. 
Max Weber politykę rozumie jako chęć zdobycia udziału we władzy, która jest dla niego tożsama z państwem ${ }^{2}$. W przypadku stanowiącym przedmiot badań tego artykułu klasyczna forma rozumienia suwerena jako najsilniejszej partii nie ma miejsca. W sytuacji odnoszącej się do decyzji sumienia nie jest bowiem możliwe (lub jest to niezmiernie trudne) uzyskanie kompromisu wewnątrzpartyjnego. $\mathrm{Na}$ przykładzie procesu legislacyjnego niedawno procedowanej ustawy transplantacyjnej w Niemczech postaram się pokazać, jak polityczność w klasycznym rozumieniu zanika i daje pierwszeństwo sumieniu. Aby lepiej zrozumieć polityczne procesy, spójrzmy najpierw na sytuację dawstwa pośmiertnego w Niemczech.

\section{DAWSTWO POŚMIERTNE W NIEMCZECH}

Sytuacja pośmiertnego dawstwa organów w Niemczech nie wygląda najlepiej. Liczba dawców od paru lat utrzymuje się na bardzo niskim poziomie. W 2010 roku było jeszcze 1296 dawstw po śmierci dawcy, w 2017 roku liczba ta osiągnęła swój najniższy poziom - wynosiła 797 przeszczepów. Rok 2018 przyniósł niewielki wzrost, odnotowano 955 przeprowadzonych przeszczepów. Jest to o 340 mniej niż przed dziewięcioma laty. Aby otrzymać pełen obraz mizerii, trzeba dodać, że liczba osób oczekujących na przeszczep w tym kraju wynosi $9400^{3}$. W ostatnich dwóch latach liczba dawców pośmiertnych była najniższa od czasu wprowadzenia w 1997 roku ustawy transplantacyjnej - Transplantationsgesetz (TPG) ${ }^{4}$. Problem jest niestety jeszcze większy — dane Niemieckiej Fundacji Dawstwa Organów (Deutsche Stiftung für Organspende - DSO) pokazują spadek z i tak już niskiego poziomu. Niemcy z danymi statystycznymi 10,6 dawstw organów na milion mieszkańców plasują się na 23. pozycji w porównaniu z dawstwem europejskim: za Polską, Słowacją i Szwajcarią, a przed Bułgarią i Rumunią․ Jest to problem, którego sprawnie funkcjonujący rząd nie można lekceważyć — codziennie umierają ludzie, gdyż nie otrzymują na czas odpowiedniego organu ${ }^{6}$.

2 M. Weber, Polityka jako zawód i powołanie, Kraków 1998, s. 56.

3 Raport roczny Niemieckiej Fundacji Dawstwa Organów - Deutsche Stiftung für Organspende (DSO): Dawstwo organów i transplantacja w Niemczech w 2018 r. (Jahresbericht Organspende und transplantation in Deutschland 2018), s. 64, https://dso.de/SiteCollectionDocuments/DSO_Jahresbericht_2018.pdf (dostęp: 15.08.2019).

${ }^{4}$ Gesetz über die Spende, Entnahme und Übertragung von Organen und Geweben (Transplantationsgesetz - TPG), (z 4.09.2007, BGB1. I, s. 2206), https://www.gesetze-im-internet.de/tpg/ TPG.pdf (dostęp: 15.08.2019).

5 Zob. statystyki: https://www.statista.com/statistics/537908/deceased-organ-donor-rate-in-europe/ (dostęp: 15.08.2019).

6 Tu zdania ekspertów są podzielone - Julia Rohe, konsultantka w przeszczepach nerek, twierdzi, że takie ujęcie problemu jest niezgodnie z prawdą; jej zdaniem: „ludzie umierają, gdyż są chorzy" - wypowiedź z dnia 6 grudnia 2019 roku; zob. https://dso.de/SiteCollectionDocuments/ DSO_Jahresbericht_2018.pdf, s. 12-15 (dostęp: 15.08.2019). 
Rząd Niemiec wystąpił więc w 2018 roku z projektem ustawy, która ma poprawić przede wszystkim infrastrukturę dawstwa organów. Pierwsza ustawa zmieniająca TPG weszła w życie w kwietniu 2019 roku$^{7}$. Minister zdrowia Jens Spahn, znany już jako minister pragnący daleko idących zmian w systemie zdrowotnym, chciał jednak pójść dalej i wprowadzić do niemieckiego systemu transplantacyjnego instytucję podwójnego sprzeciwu (doppelte Wiederspruchlösung $)^{8} \mathrm{w}$ procesie pobierania organów ${ }^{9}$. Podobny system od lat funkcjonuje w Polsce. Plany ministra zostały poparte przez kanclerz Niemiec Angelę Merkel. Niemożliwe politycznie było jednak uzyskanie większości poparcia w koalicji rządzącej, która obecnie potocznie nazywana jest „Wielką Koalicją” (Grosse Koalition), a składa się z centroprawicowej CDU/CSU oraz z partii socjaldemokratycznej SPD. Aby obejść spory międzypartyjne, zostały stworzone dwa projekty poselskie i jeden wniosek poselski, które w czerwcu 2019 roku poddano debacie przed Bundestagiem. Pierwszy z nich to projekt ustawy regulującej podwójny sprzeciw w ustawie transplantacyjnej ${ }^{10}$ (tak zwany model opt out), drugi, mniej radykalny, to projekt ustawy wzmacniającej gotowość do podjęcia decyzji o dawstwie organów (tak zwany model opt in $)^{11}$. Trzeci z nich, w formie wniosku do rządu o przygotowanie projektu, to inicjatywa posłów AfD — partii odczuwającej w Bundestagu polityczny ostracyzm z uwagi na skrajnie prawicowe poglądy. To jedyny projekt, który nie ma charakteru międzypartyjnego, choć jego założenia nie są odległe od założeń modelu opt in. Przygotowany przez posłów AfD projekt „Więcej zaufania do dawstwa organów - rozwiązanie przez zaufanie" nie miał jednak politycznie szans na to, aby stać się prawem ${ }^{12}$.

Projekty wywołały sporą dyskusję zarówno w mediach, jak i w doktrynie. Aby zaobserwować aspekt dynamiczny polityczności prawa, czyli uchwycić polityczność $\mathrm{w}$ fazie jego powstawania, istotne jest na początek przybliżenie założenia obecnie funkcjonującego prawa oraz założeń powstałych projektów.

7 Zweites Gesetz zur Änderung des Transplantationsgesetzes (z 22.03.2020, BGB1 1, s. 352). Celem zmian jest przede wszystkim polepszenie współpracy pomiędzy strukturami szpitali przeprowadzającymi transplantacje i pobierającymi organy. Otrzymają one lepsze finansowanie, zmieniły się również przepisy dotyczące prowadzenia dokumentacji transplantacji oraz opieki nad bliskimi; zob. https://www.bundesgesundheitsministerium.de/gzso.html (dostęp: 15.08.2019).

${ }^{8}$ Znane też pod nazwą dorozumianej zgody. W razie braku oświadczenia woli przyjmuje się, że osoba w razie zaistnienia śmierci mózgu jest gotowa oddać swoje organy.

9 Podobny system od lat funkcjonuje w Polsce; zob. ustawa z dnia 1 lipca 2005 roku o pobieraniu, przechowywaniu i przeszczepianiu komórek, tkanek i narządów, Dz.U. z 2019 r. poz. 1405 (dalej: UTran).

${ }^{10}$ Entwurf eines Gesetzes zur Regelung der doppelten Widerspruchslösung in Transplantationsgesetz, Drucksache 19/11096, 25.06.2019 roku.

${ }^{11}$ Entwurf eines Gesetzes zur Stärkung der Entscheidungsbereitschaft bei der Organspende, Drucksache 19/11087, 25.06.2019 roku.

12 Mehr Vertrauen in die Organspende - Vertrauenslösung, Drucksache 19/11124. 


\section{DOTYCHCZASOWA REGULACJA PRAWNA I PRAKTYKA}

Istnieją różne modele udzielenia zgody na dawstwo organów. Zgodnie z modelem uzyskania zgody (opt in) dawstwo jest możliwe tylko po uzyskaniu takiej zgody osoby zmarłej za jej życia. Ten model obowiązuje w niektórych krajach Europy ${ }^{13}$ oraz w USA ${ }^{14}$. W przeciwieństwie do modelu zgody stoi model sprzeciwu (opt out), w którym organy mogą być pobrane, jeżeli sprzeciw dawcy jest nieznany. Ten model ma zastosowanie w większości państw Europy ${ }^{15}$. Rozróżnienie pomiędzy modelami zgody i sprzeciwu często prowadzi do nieporozumień. Pojęcia te wzbudzają niejednokrotnie wątpliwości oraz obawy, że gdy nie ma jasnej decyzji, jak na przykład istniejący dokument dawcy, w modelu zgody oznacza to zawsze niewyrażenie zgody na dawstwo, a w modelu sprzeciwu, w przypadku jego braku, zawsze będzie dochodziło do dawstwa. Taki stan rzeczy nie występujące jednak w praktyce ani nie jest przewidziany przez prawo.

Zgodnie z prawem w Niemczech obowiązuje tak zwane rozwiązanie decyzyjne - Entscheidungslösung ${ }^{16}$. Ten rodzaj decyzji jest w założeniu modelem uzyskania zgody. Nazwę można wyjaśnić tym, że na początku procesu należy przedstawić decyzję dawcy. Zasadniczo pobór organu może nastąpić, wyłącznie jeśli istnieje jasna zgoda (§ 3 ust. 1 nr 1 TPG). Zgodnie z $§ 4$ TPG lekarz, który opiekuje się potencjalnym dawcą, gdy nie ma pisemnej zgody lub pisemnego sprzeciwu, zwraca się do najbliższych potencjalnego dawcy. Przy czym zadawanie pytania bliskim następuje $\mathrm{w}$ dwóch fazach. Pierwszym pytaniem jest, czy potencjalny dawca za życia złożył oświadczenie dotyczące dawstwa organów. Jeżeli nie ma takiego oświadczenia, nie oznacza to jednak, że do pobrania nie może dojść. Lekarz prowadzący zadaje drugie pytanie: czy bliscy wyrażają zgodę na pobranie organu - czyli to bliscy decydują o pobraniu. W swojej decyzji krewni zmarłego powinni respektować domniemaną wolę potencjalnego dawcy. Pytanie o zgodę jest zadawane w czterech krokach: czy istniało pisemne oświadczenie, czy istniało oświadczenie w stosunku do bliskich, jaka była domniemana wola potencjalnego dawcy i jaka jest decyzja bliskich. Dopiero po tych czterech krokach można w razie zgody bliskich pobrać organy.

13 Na przykład w Danii, Niemczech, Irlandii, na Litwie, w Holandii, Rumunii, na Cyprze; zob. https://transplant.goeg.at/Jahresbericht2018, s. 10 (dostęp: 17.08.2019).

14 R.H. Thaler, C.R. Sunstein, Nudge: Improving Decisions About Health, Wealth and Happines, London 2008, s. 4.

15 W Belgii, Bułgarii, Finlandii, Francji, Grecji, Chorwacji, na Malcie, w Norwegii, Łotwie, Luksemburgu, Austrii, Polsce, Portugalii, Słowacji, Słowenii, Hiszpanii, Czechach, Węgrzech; zob. https://transplant.goeg.at/Jahresbericht2018, s. 10 (dostęp: 17.08.2019).

16 Zob. projekt ustawy w sprawie regulacji rozwiązania decyzyjnego w ustawie transplantacyjnej TPG, BT-Drucksache 17/9030. 


\section{GŁÓWNE ZAŁOŻENIA PROJEKTÓW}

\subsection{PROJEKT PODWÓJNEGO SPRZECIWU - ZASADA OPT OUT}

W celu zwiększenia liczby przeprowadzanych transplantacji powstał projekt poselski wprowadzający wspomniany już model sprzeciwu. W tym wypadku jest to model podwójnego sprzeciwu, czyli tak zwanego miękkiego sprzeciwu ${ }^{17}$. Zgodnie z tym modelem każdy może podczas swojego życia sprzeciwić się pobraniu organu odpowiednim zapisem w rejestrze sprzeciwów lub sporządzając pisemne oświadczenie. Jednak jeżeli nie zarejestrowano sprzeciwu lub brakuje jego pisemnej formy, lekarz prowadzący jest zobowiązany spytać bliskich, czy wiedzą o istnieniu woli zmarłego sprzeciwiającej się pobraniu jego organów ${ }^{18}$. Znaczenie ma zatem tylko wola potencjalnego dawcy — określenie „podwójny sprzeciw" wprowadza w błąd, gdyż miarodajna jest jedynie wola potencjalnego dawcy, a nie jego bliskich. W praktyce łatwo można jednak wyobrazić sobie przypadki, w których wola potencjalnego dawcy zostanie zastąpiona wolą jego bliskich. W wypadku takiego uregulowania niewiele się zmieni. Zmieni się natomiast teoretyczne podejście do problemu, rysujące obraz etycznego postrzegania naszego ciała, oraz przesunięcie ciężkości dowodu w imię zasady in dubio pro quaestus — w razie wątpliwości na korzyść pobrania organu.

Czym innym jest wyrażenie altruistycznej zgody na pobranie organu, a czym innym uznanie milczenia za zgodę na pobranie organu. W obecnych czasach nasze dobra osobiste podlegają ścisłej ochronie prawnej ${ }^{19} \mathrm{i}$ ich ujawnianie, zgodnie z prawem, powinno odbywać się za naszą zgodą. Jeżeli jednak chodzi o nasze organy, to - w imieniu dobra publicznego - nasza zgoda jest domniemana $\mathrm{w}$ wypadku milczenia. Instytucja zgody domniemanej ma w prawie marginalne znaczenie ${ }^{20}$.

17 W odróżnieniu od twardego sprzeciwu, który jest stosowany na przykład w Polsce. Zgodnie z art. 5 ust. 1 UTran organ pobiera się, gdy osoba zmarła nie wyraziła sprzeciwu. Sprzeciw można wyrazić zgodnie z art. 6 ust. 1 pkt 1-3 UTran przez wpisanie sprzeciwu do rejestru, pisemne podpisane własnoręcznie oświadczenie lub oświadczenie ustne złożone w obecności dwóch świadków i pisemnie przez nich potwierdzone.

$18 \S 4$ ust. 1 projektu ustawy Drucksache 19/11096.

19 Chociażby niedawno znowelizowana ustawa z dnia 10 maja 2018 roku o ochronie danych osobowych, Dz.U. z 2018 r. poz. 100.

20 Na przykład w niemieckim prawie handlowym art. 362 niemieckiego kodeksu handlowego (HGB). Por. J. Wróbel, Zgoda domniemana w polskiej ustawie transplantacyjnej. Watpliwości i obawy natury etycznej, [w:] Etyczne aspekty transplantacji narzadów, red. A. Marcol, Opole 1996, s. 36; P.G. Nowak, Problemy etyczne transplantologii. Perspektywa niedoboru narządów do przeszczepu, „Diametros” 42, 2014, s. 150-177. 


\subsection{PROJEKT WZMOCNIENIA GOTOWOŚCI DO DAWSTWA ORGANÓW - ZASADA $O P T I N$}

Drugi projekt poselski pozostawia funkcjonujący do tej pory w Niemczech model zgody. Wprowadza jednak pewne ulepszenia systemu alokacji i struktur w transplantacji, widząc w tym metodę na zwiększenie gotowości do dawstwa.

Obywatelom powinno być łatwiej udokumentować swoją decyzję i dokonać jej zmiany. Do tego celu ma zostać stworzony rejestr online przy Niemieckim Instytucie Dokumentowania i Informacji Medycznej (Deutscher Institut für Medizinische Dokumentation und Information). Możliwość oddania oświadczenia będzie również możliwa w momencie złożenia wniosku o dowód osobisty ${ }^{21}$. Projekt przewiduje także zwiększanie kampanii informacyjnej - tu obowiązek informacyjny został nałożony na lekarzy Hausartzt, którzy co dwa lata powinni przeprowadzać rozmowę informacyjną ze swoimi pacjentami, za co mogą pobierać dodatkową opłatę finansowaną przez system opieki zdrowotnej ${ }^{22}$. Zwiększone zostaną wydatki na koordynatorów ds. transplantacji i szpitale ich dokonujące. Rozwiązania tego projektu opierają się na doświadczeniach z Hiszpanii i Szwecji, gdzie postawiono przede wszystkim na odbudowanie zaufania obywateli do systemu zdrowotnego i w ten sposób zwiększono liczbę osób decydujących się na świadome oddawanie organów ${ }^{23}$.

Drugi projekt pozostaje przy starej zasadzie opt in, co argumentuje tym, że nakładanie obowiązku dawstwa jest niezgodne z niemiecką konstytucją i prowadzi do naruszeń praw podstawowych obywateli ${ }^{24}$. Skoro nie ma znacznej różnicy w liczbie transplantacji organów między państwami z systemem opt out i opt in, to w takim razie po co wprowadzać kolejny obowiązek dla obywateli, który może potencjalnie naruszać ich prawa ${ }^{25}$.

\subsection{MODEL WZMOCNIENIA ZAUFANIA}

Frakcja polityczna AfD złożyła poselski wniosek ustawowy ${ }^{26}$ zatytułowany: „Więcej zaufania do dawstwa organów — rozwiązanie przez zaufanie” (Mehr Vertrauen in die Organspende - Vertrauenslösung). Przewiduje on możliwość zwięk-

${ }^{21}$ Deutscher Bundestag, Drucksache 19/11087 z 25.06.2019 roku, s. 3.

22 Ibidem.

23 W. Kluth, B. Sander, Verfassungsrechtliche Aspekte einer Organspendepflicht, „Deutsches Verwaltungsblatt" 1997, s. 1285 n.

${ }^{24}$ F. Kelle, Wiederspruchlösung und Menschenwüde, eine verfassungsrechtliche Untersuchung zur Begründbarkeit einer Organspendpflicht und zur Vereinbarkeit von Menschenwürde und Wiederspruchlösung unter Berücksichtigung ethischer und medizinischer Aspekte, „Schriftenreihe Medizin-Ethik-Recht" 31, 2011, s. 21 n.

25 Wystąpienie A. Baerbock (Bündnis 90/die Grünen) w Bundestagu podczas posiedzenia 26 czerwca 2019 roku - Drucksache 13020.

${ }^{26}$ Nie jest to projekt ustawy, a wniosek o podjęcie inicjatywy ustawodawczej - Antrag „Mehr Vertrauen in die Organspende - Vertrauenslösung”, Drucksache 19/11124 z 25.06.2019 roku. 
szenia liczby dawstw przez polepszenie zaufania obywateli do systemu opieki zdrowotnej. Na tej podstawie każdy obywatel będzie mógł podjąć własną decyzję opartą na znajomości medycznego toku postępowania. Tu pojawia się krytyka ostatnich zmian w prawie transplantologicznym, które zdaniem AfD wprowadziły sceptycyzm społeczeństwa, nie zaś transparentność uregulowań.

Istotne według projektu jest, aby nie tylko cały proces poszukiwania i umieszczania narządów był regulowany przez organizacje pozarządowe, lecz także aby kontrola nad tym procesem podlegała tym samym organizacjom. Posłowie wzywają między innymi do przekazania nadzoru i kontroli nad organem koordynującym i przeprowadzającym mediacje niezależnej urynkowionej instytucji prawa publicznego. Ma to służyć odpolitycznieniu tych organizacji i ograniczeniu roli finansowych interesów w dziedzinie transplantacji. Pozostaje jednak problem, czy w wypadku tych organizacji nie będzie dochodziło do nadużyć w tej bardzo wrażliwej etycznie kwestii.

\section{POLITYCZNOŚĆ PRAWA W FAZIE SKŁADANIA PROJEKTÓW}

Pierwszy z projektów, postulujący wprowadzenie podwójnego sprzeciwu, został zaproponowany przez ministra zdrowia Jensa Spahna (CDU/CSU) i eksperta SPD Karla Lauterbacha oraz przez dr. Georga Nüßleina (CSU), dr Petrę Sitte (Die Linke) i innych posłów ${ }^{27}$. W tym kontekście 31 marca 19 posłów Bundestagu, skupionych wokół Stephana Pilsingera (CSU), Ulli Schmidt (SPD) i Annaleny Baerbock (Bündnis 90/die Grünen), przedstawiło również kluczowe punkty konkurencyjnej nowej regulacji dawstwa narządów ${ }^{28}$. Regulacją tą zdecydowanie odrzucają model sprzeciwu i wraz z innymi członkami lewicy FDP i CDU dążą do wypracowania wiążącego międzypartyjnego modelu zgody. Mamy tu odczynienia z projektami niepartyjnymi, które nie reprezentują przekonań politycznych odpowiednich partii, tylko personalne preferencje poszczególnych członków Bundestagu. Jedynym czysto partyjnym projektem pozostaje ten złożony przez AfD. Jest to spowodowane tym, że AfD jest partią prawicową, skazaną na samotność polityczną w Bundestagu. Nikt z posłów innej partii nie może przyłączyć się do tego projektu, nawet jeżeli byłby on racjonalny, ze względu na utratę wiarygodności w oczach wyborców. Pozostałe dwa projekty nie mają nic wspólnego z działaniami prowadzonymi na rzecz konkretnej partii, ich zwolennicy nie są związani dyscypliną partyjną, a projekty powstały w porozumieniu międzypartyjnym poszczególnych posłów optujących za danym rozwiązaniem problemu (poza posłami AfD, którzy będą głosowali za własnym wnioskiem). W jednym i drugim zespole widzimy przedstawicieli zarówno lewicy, jak i prawicy,

27 Entwurf eines Gesetzes zur Reglung der doppelten Widerspruchlösung in Transplantationsgesetz, Drucksache 19/11096 z 25.06.2019 roku.

28 Entwurf eines Gesetzes zur Stärkung der Entscheidungsbereitschaft bei der Organspende, Drucksache 19/1187 z 25.06.2019 roku. 
partii centralnych i liberalnych. Najwyraźniej problem spojrzenia na własne ciało jest tak osobisty, że stał się kwestią ponadpartyjną.

\section{POLITYCZNOŚĆ PRAWA — SYSTEM PRZYDZIAŁU LIMITU CZASU WYSTĄPIEŃ I LICZBY POWOŁYWANYCH EKSPERTÓW}

W kontekście dynamicznym i epistemologicznym polityczności prawa znaczenie mają zasady, według których funkcjonuje przydzielanie liczby i czasu wystąpień podczas debaty parlamentarnej oraz przyznanie liczby ekspertów sporządzających opinię dla poszczególnych partii w celu dalszych konsultacji w Bundestagu. W wypadku projektów składanych przez poszczególne partie wartości te oblicza się na tych samych zasadach co liczbę miejsc do obsadzenia w komisjach parlamentarnych. Wartość ta jest proporcjonalna w stosunku do siły politycznej poszczególnych partii w Bundestagu. Ta wartość z kolei zależy od głosów uzyskanych w ostatnich wyborach parlamentarnych. W celu wyłonienia odpowiednich wartości przeprowadza się specjalne postępowanie. Stosowaną matematyczną formułą są metody Hare/Niemeyer albo d'Hondt, Sainte-Laguë/Schepers. W omawianym szczególnym przypadku $-\mathrm{z}$ uwagi na to, że poszczególne projekty zostały złożone przez posłów z różnych partii - zastosowano wskazane formuły, za podstawę przyjmując nie siłę polityczną, lecz liczbę posłów podpisanych pod każdym z projektów. Pod uwagę została wzięta liczba posłów podpisanych pod projektem opt in, projektem opt out, projektem AfD oraz grupa posłów niezdecydowanych ${ }^{29}$. Ponieważ projekty opt in i opt out zostały podpisane przez porównywalną grupę posłów, został im przyporządkowany podobny czas na przemówienia. Przy powoływaniu ekspertów, w celu odbycia konsultacji publicznych, wzięto pod uwagę tylko dwa projekty i wniosek AfD. Oznacza to odstąpienie od tradycyjne rozumianej polityczności na rzecz liczby głosów poparcia danego projektu/wniosku.

\section{POLITYCZNOŚĆ PRAWA — DEBATA PARLAMENTARNA Z 26 CZERWCA 2019 ROKU}

\subsection{ARGUMENTY ZA MODELEM SPRZECIWU - PRZECIWKO MODELOWI ZGODY Z WYSZCZEGÓLNIENIEM MÓWCÓW POSZCZEGÓLNYCH PARTII POLITYCZNYCH}

1. Statystyki pokazują, że jest wiele osób popierających dawstwo organów, lecz aktywnie niepodejmujących decyzji. W takim wypadku model sprzeciwu wykorzystywałby gotowość do dawstwa ze strony społeczeństwa - dr G. Nüßlein,

29 Deutscher Bundestag — berechnungsverfahren für die Sitzverteilung, https://www.bundestag.de/ausschuesse/azur-532274 (dostęp: 20.12.2019). 
(CDU/CSU), H.O. Solms (FDP), dr C. Schmidtke (CDU/CSU), dr K. Lauterbach (SPD).

2. Zasada solidarności: 95\% osób zgadza się na otrzymanie organu. W związku z tym ten sam procent osób powinien być potencjalnymi dawcami, za czym przemawia również zasada odpowiedzialności za inne osoby i interes publiczny — dr G. Nüßlein (CDU/CSU), dr K. Leikert (CDU/CSU), G. Connemann (CDU/ CSU), P. Sitte (Die Linke), T. Oppermann (SPD), O. Fricke (FDP).

3. Chrześcijańska pomoc innemu człowiekowi w wypadku zagrożenia jego życia, prawo do życia — dr G. Nüßlein (CDU/CSU), T. Oppermann (SPD).

4. Porównanie do instytucji testamentu — jeżeli go nie napiszę, muszę liczyć się z tym, że po mojej śmierci będzie stosowane dziedziczenie ustawowe - dr G. Nüßlein (CDU/CSU).

5. Teoria uniwersalizmu I. Kanta: etycznie mogę wymagać modelu sprzeciwu - tego, czego chcę mieć dla siebie, mogę wymagać od innej osoby — dr K. Lauterbach (SPD).

6. Możliwość wniesienia sprzeciwu zapewnia nienaruszalność praw podstawowych. Projekt wprowadza obowiązek do odpowiedzi na pytanie, a nie obowiązek dawstwa organów — dr K. Lauterbach (SPD), T. Sorge (CDU/CSU), J. Spahn (CDU/CSU), T. Oppermann (SPD), S. Dittmar (SPD).

7. Prawo do samostanowienia, $\mathrm{z}$ którego powinno się korzystać w tak ważnych kwestiach - J. Spahn (CDU/CSU).

\subsection{ARGUMENTY ZA MODELEM ZGODY - PRZECIWKO MODELOWI SPRZECIWU Z WYSZCZEGÓLNIENIEM MÓWCÓW POSZCZEGÓLNYCH PARTII POLITYCZNYCH}

1. Prawo do nienaruszalności własnego ciała — art. 1 i 2 niemieckiej konstytucji (Grundgesetz — GG), mające szczególne znaczenie w Niemczech ze względu na historię - A. Baerbrok (Bündnis 90/die Grünen), N. Movassat (Die Linke).

2. Nieproporcjonalność rozwiązania — te same efekty można uzyskać bez ograniczenia praw i wolności osobistych. Przykład Hiszpanii pokazuje, jak to uczynić poprzez lepszą organizację i skomunikowanie szpitali, zaufanie do służby zdrowia, wprowadzenie rejestrów online oraz tak zwaną politykę przekonania (nudgging) - A. Baerbrok (Bündnis 90/die Grünen), J. Meier (AfD), K. Mag (CDU/ CSU), H. Mattheis (SPD), K. Vogler (Die Linke), K. Kappert-Gonther (Bündnis 90/die Grünen), S. Pilsinger (CDU/CSU).

3. Ograniczenie prawa do samostanowienia; wprowadzenie obowiązku do podejmowania decyzji stanowi zburzenie kultury prawnej (Bruch der Rechtskultur) — J. Meier (AfD), K. Mag (CDU/CSU), S. Pilsinger (CDU/CSU).

4. Możliwość nadużyć w fazie zgonu, podniesienie pytania, czy osoba ze śmiercią mózgu jest rzeczywiście martwa — J. Meier (AfD), U. Oehme (AfD), P.V. Podolay (AfD). 
5. Świadoma i dobrowolna zgoda powinna być podstawą podejmowania decyzji. Dawstwo organów to etyczny obowiązek, a nie państwowy przymus. Takie rozwiązanie to instrumentalizacja i patronizacja ze strony państwa - K. Mag (CDU/CSU), Ch. Aschenberg-Dungus (FDP), K. Vogler (Die Linke), P.V. Podolay (AfD), D. Nietan (SPD), N. Movassat (Die Linke).

6. Milczenie nie może oznaczać zgody - K. Kappert-Gonther (Bündnis 90/ die Grünen), S. Pilsinger (CDU/CSU).

7. Kolejny obowiązek ze strony państwa, który wzbudza niepokój - K. Mag (CDU/CSU), S. Pilsinger (CDU/CSU).

8. Ludzie nie są maszynami, z których można wycinać części zamienne, pieniądze byłoby lepiej przeznaczyć na zapobieganie chorobom - P.V. Podolay (AfD).

\subsection{OCENA}

Z przedstawionego zestawienia można wywnioskować, że argumenty zaprezentowane przez poszczególnych mówców nie są jednoznacznie związane ze światopoglądem politycznym reprezentowanym przez dane partie. Wyjątkiem od tej zasady są posłowie AfD, którzy w całości opowiedzieli się za modelem opt in, stawiając zgodnie w centrum krytyki uznanie śmierci mózgu za kryterium śmierci. Inni mówcy nie podejmują tego tematu, nie chcąc podawać tego uregulowanego prawnie kryterium pod wątpliwość. Inne argumenty używane przez polityków AfD odpowiadają argumentom posłów z reszty partii. W sumie 10 mówców było za modelem opt out, a 12 za modelem opt in, czyli zgodnie z oczekiwaniami i systemem podziału głosów proporcjonalnie do listy osób, które podpisały poszczególne projekty, większość przypada na system opt in.

Najbardziej podzielone zdania są w najliczniejszych partiach, które obejmują swoim programem szerszą reprezentację społeczną, czyli we frakcji CDU/CSU oraz w SPD, co też jest logiczne.

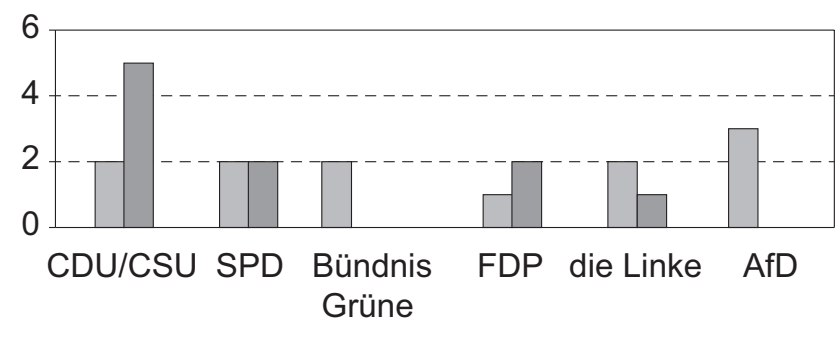

za modelem opt in $\quad \square$ za modelem opt out

Ilustracja 1 . Wypowiedzi posłów podczas debaty z podziałem na partie

Źródło: opracowanie własne. 


\section{POLITYCZNOŚĆ PRAWA - OPINIE POSZCZEGÓLNYCH EKSPERTÓW}

Niestety, w celu stania na straży wolności wypowiedzi nie jest ujawnione, którzy eksperci zostali powoływani przez zwolenników poszczególnych modeli. Dlatego też w dalszej części artykułu zostaną przedstawione argumenty podnoszone przez poszczególnych ekspertów.

\subsection{ARGUMENTY EKSPERTÓW ZA MODELEM SPRZECIWU (OPT OUT) - Z WYSZCZEGÓLNIENIEM POSZCZEGÓLNYCH EKSPERTÓW}

1. Dane statystyczne prowadzone w państwach, w których funkcjonują systemy opt in i system opt out ${ }^{30}$, potwierdzają, iż istnienie modelu opt out wiąże się z wyższym wskaźnikiem dawców narządów, nawet jeśli weźmie się pod uwagę inne czynniki wpływające na dawstwo narządów ${ }^{31}$. Model opt out jest więc jedyną szansą na zwiększenie liczby dawstw i zmniejszenie odsetka pacjentów, którzy umierają z powodu nieotrzymania organów ${ }^{32}$ — Niemiecka Fundacja Transplantacji Organów (DSO) ${ }^{33}$, prof. Kai Uwe Eckardt ${ }^{34}$, Gudrun Ziegler ${ }^{35}$, Niemieckie Towarzystwo Transplantacyjne ${ }^{36}$, dr Fritz Diekmann ${ }^{37}$.

2. Model opt out można rozumieć jako „społeczną zgodę na dawstwo organów"38. W związku z tym, że większość obywateli Niemiec popiera pośmiertne dawstwo organów, taka organizacja sytemu ustanawia pozytywną sytuację wyjściową ${ }^{39}$

30 A. Rithalia et al., Impact of presumed consent for organ donation on donation rates: a systematic review, „The BMJ” 2009, nr 338, s. 3162-3168.

31 Zob. opinia, https://www.bundestag.de/resource/blob/658848/f48b91ed8808d82230b91 1b9e3c42983/19_14_0095-17-_Deutsche-Stiftung-Organspende_Organspende-data.pdf (dostęp: 31.12.2019).

32 Zob. opinia, https://www.bundestag.de/resource/blob/660562/60c5aa266bf4efc0fca4ee 532671ae40/059_25-09-2019_Organspende-data.pdf (dostęp: 31.12.2019).

33 Deutsche Stiftung Organtransplantation, https://dso.de/ (dostęp: 23.01.2020).

34 Dyrektor kliniki nefrologicznej w Charité Berlin.

35 G. Ziegler była przewodnicząca Zarządu Forum Transplantacji Organów w Berlinie.

36 Szczegóły dotyczące organizacji zob. www.d-t-g-online.de (dostęp: 17.12.2019).

37 Profesor uniwersytetu w Barcelonie zajmujący się transplantacją nerek. Zob. opinia, https:// www.bundestag.de/resource/blob/658850/75cbe3ed06aa0230554cd2376f66d166/19_14_0095-18ESV-Dr-Fritz-Diekmann-data.pdf (dostęp: 17.12.2019).

38 Moralny obowiązek do podjęcia decyzji; zob. https://www.br.de/nachrichten/deutschlandwel-t/organspende-widerspruchsloesung-sinnvoll,RMN7AH2 (dostęp: 31.12.2019).

39 Zob. opinia, https://www.bundestag.de/resource/blob/658846/f828aa9eadad3ffce4cea6bfc38586b5/19_14_0095-16-_ESV-Prof-Dr-Dr-Eckhard-Nagel_Organspende-data.pdf (dostęp: 31.12.2019). 
- prof. dr Eckhard $\mathrm{Nagel}^{40}$, prof. dr med. Urlich Kunzendorf ${ }^{41}$, Leben Spenden e.V. ${ }^{42}$, TransDia Sport Deutschland e.V. ${ }^{43}$

3. Można oczekiwać, że prawie każdy obywatel, po prawnie uregulowanej informacji przez kasę chorych, zajmie się kwestiami dawstwa narządów i tkanek oraz podejmie wiążącą decyzję za lub przeciw dawstwu. Wprowadzenie modelu sprzeciwu można rozumieć jako spełnienie „obowiązku państwa do ochrony życia ludzkiego i zabezpieczenie interesu publicznego". Ograniczenie zaś prawa do samostanowienia można uznać za proporcjonalne, nienaruszające ani ludzkiej godności, ani wolności przekonań, ponieważ zasadniczo pozostawia prawo do samodzielnego decydowania, a także dlatego że nie zmusza do ujawnienia powodów podjętej decyzji ${ }^{44}$ - Federalna Izba Lekarska - Bundesärztekammer, prof. dr Kai Uwe Eckardt ${ }^{45}$, Leben Spenden e.V., Niemieckie Towarzystwo Transplantacyjne ${ }^{46}$.

4. Zasada solidarności społecznej wynikająca z art. 20 ust. 1 niemieckiej konstytucji. Takie ustanowienie prawa jest obowiązkiem państwa socjalnego ${ }^{47}$ - Junge Helden e.V. ${ }^{48}$

5. Wyraz solidarności wewnątrz krajów należących do Eurotransplantu Eurotransplant ${ }^{49}$.

40 Członek Niemieckiej Rady Etycznej; zob. https://www.ethikrat.org/ (dostęp: 9.01.2020).

${ }^{41}$ Dyrektor kliniki chorób nerek w Kiel. Zob. opinia, https://www.bundestag.de/resource/ blob/658468/86ab64722f9a10bd18be4b32420426c2/19_14_0095-1-_ESV-Prof-Dr-Kunzendorf_ Organspende-data.pdf (dostęp: 31.12.2019).

42 Organizacja użyteczności publicznej, będąca inicjatywą lekarzy, polityków i innych osób, podejmujących działania na rzecz dawstwa organów w społeczeństwie niemieckim. Zob. opinia, https:// www.bundestag.de/resource/blob/589412/e5baf6f46a1f5ae1 f927b90719c72911/19_14_0056-6Junge-Helden_Organspende-data.pdf (dostęp: 16.12.2019).

43 Stowarzyszenie sportowe użytku publicznego dla osób dializowanych i po transplantacjach. Zob. opinia, https://www.bundestag.de/resource/blob/589304/6b250fa69f25e8a4ca3595cf15 af8982/19_14_0056-1__TransDia_Organspende-data.pdf9 (dostęp: 16.12.2019).

44 Zob. opinia, https://www.bundestag.de/resource/blob/658474/34438a8a0db01476ecd6791 ab2bd954b/19_14_0095-4-_BAeK_Organspende-data.pdf (dostęp: 31.12.2019).

45 Dyrektor kliniki nefrologicznej w Charité Berlin. Zob. opinia, https://www.bundestag. de/resource/blob/658512/6344fa69b38ab2b8de09749f8d768860/19_14_0095-5-_ESV-Prof-DrEckardt_Organspende-data.pdf (dostęp: 31.12.2019).

${ }_{46}$ Zob. opinia, https://www.bundestag.de/resource/blob/658838/7fd6080f2d2f859654f2ae22d19e099e/19_14_0095-12-_Deutsche-Transplantationsgesellschaft_Organspende-data.pdf (dostęp: 17.12.2019).

47 Zob. opinia, https://www.bundestag.de/resource/blob/658636/ce7ea5af6bb77049d02fb1b5ef663e56/19-14-0095-7-_Junge-Helden-eV_Organspende-data.pdf (dostęp: 17.12.2019).

48 Stowarzyszenie użyteczności publicznej, które zostało stworzone w celu wspierania dawstwa organów Szczegóły dotyczące organizacji zob. http://junge-helden.org/ (dostęp: 17.12.19).

49 Zob. opinia, https://www.bundestag.de/resource/blob/658844/3f214084ddcecf0e3f911a9b6389a9eb/19_14_0095-15-_Eurotransplant_Organspende-data.pdf (dostęp: 17.12.2019). 


\subsection{ARGUMENTY EKSPERTÓW ZA MODELEM ZGODY (OPT IN) - Z WYSZCZEGÓLNIENIEM POSZCZEGÓLNYCH EKSPERTÓW}

1. Proponowane wprowadzenie systemu sprzeciwu może spowodować naruszenie praw podstawowych gwarantowanych przez niemiecką konstytucję $e^{50}$. W związku z tym ustawa musiałaby być tak ukształtowana, aby była wolna od wszelkiego rodzaju możliwości jej nadużyć, a złożenie sprzeciwu powinno być możliwe ze strony obywateli w każdym momencie w sposób niebiurokratyczny oraz dokumentowane w rejestrze sprzeciwów, dowodzie, prawie jazdy i karcie ubezpieczenia zdrowotnego - prof. dr Friedrich Hufen ${ }^{51}$, prof. dr Winfried Kluth $^{52}$, prof. dr Heinrich Lang ${ }^{53}$.

2. Milczenie nie oznacza wyrażenia zgody. Zasada ta ma zastosowanie do ochrony konsumentów i danych oraz do prawa medycznego. Stanowi również demokratyczną zasadę - wstrzymanie się od głosu nie jest liczone jako „tak”. Proponowany projekt ustawy ma na celu odejście od tej zasady w bardzo delikatnej etycznej kwestii. Wraz z regulacją sprzeciwu zwiększa się niebezpieczeństwo, iż ludzie staną się dawcami narządów wbrew swojej woli ${ }^{54}$ - Eugen Brysch $^{55}$, prof. Peter Dabrock ${ }^{56}$.

3. Krytyka przyjętej terminologii podwójnego sprzeciwu: w ustawie chodzi wyłącznie o jeden sprzeciw - o sprzeciw dawcy. W razie niewyrażenia sprzeciwu bliscy powinni odtworzyć wolę zmarłego. Jeżeli sprzeciw nie jest udokumentowany, a przesłuchiwani krewni nie kłamią celowo, ciało osoby ze śmiercią mózgu

50 Godność ludzka (art. 1 ust. 1 zd. 1 GG), prawo do życia i prawo do nienaruszalności cielesnej (art. 2 ust. 2 GG), pośmiertne prawa osobowe (art. 2 ust. 1 GG w zw. z art. 2 GG), prawo do samostanowienia w stosunku do własnego ciała (art. 2 ust. $1 \mathrm{w}$ zw. $\mathrm{z}$ art. 2 ust. 2 GG), prawo wolności wyznania i wolności religijnej w obszarze obchodzenia się z ciałem (art. 4 GG), prawo własności części ciała (art. 14 GG), a także wolny rozwój osobowości w kształtowaniu prawa do niezajmowania się i nie podejmowania decyzji (art. 2 ust. $1 \mathrm{GG}$ ).

51 Profesor prawa publicznego na uniwersytecie w Miśni, członek Trybunału Konstytucyjnego Nadrenii Palatynatu. Zob. opinia, https:/www.bundestag.de/resource/blob/658514/c8cefd 864f97056103dd4760c0fc4b38/19_14_0095-6-_ESV-Prof-Dr-Friedhelm-Hufen_Organspende-data.pdf (dostęp: 29.01.2019).

52 Profesor prawa publicznego na Uniwersytecie Martina Lutra w Halle. Zob. opinia, https:// www.bundestag.de/resource/blob/658470/5a4b8665847dc20b4dc8409a1e551934/19_14_0095-2ESV-Prof-Dr-Kluth_Organspende-data.pdf (dostęp: 29.01.2019).

53 Związany z Katedrą Prawa Publicznego Uniwersytet w Greifswaldzie. Zob. opinia, https:// www.bundestag.de/resource/blob/659066/73d08d1b74563e4a37b264af61cd31a7/19_14_0095-19-_ Prof-Dr-Heinrich-Lang_Organspende-data.pdf (dostęp: 17.12.2019).

${ }_{54}$ Zob. opinia, https://www.bundestag.de/resource/blob/658672/0ef1765f18d69f43293c27fae4c758df/19_14_0095-11-_ESV-Eugen-Brysch_Organspende-data.pdf (dostęp: 17.12.2019).

55 Przewodniczący Niemieckiej Fundacji Ochrony Pacjentów (Deutsche Stiftung Patietntenschutz); zob. https://www.stiftung-patientenschutz.de/ (dostęp: 2.01.2020).

${ }^{56}$ Członek Niemieckiej Rady Etycznej, profesor filozofii na Uniwersytecie Fryderyka Aleksandra w Erlangen-Norymberdze. Zob. opinia, https:/www.bundestag.de/resource/blob/658638/ e21 ee75f803fd051d517faee8ea2d677/19-14-0095-8-_ESV-Prof-Dr-Peter-Dabrock_Organspende-data.pdf (dostęp: 19.01.2020). 
staje się, zgodnie z planowanymi zmianami, własnością państwa opiekuńczego. Właściwą nazwą tego modelu byłoby zatem „oczekiwanie na dawstwo narządów z zastrzeżeniem sprzeciwu" 57 — prof. dr Peter Dabrock.

4. Z punktu widzenia solidarności społecznej i ram instytucjonalnych „wykorzystanie" ciała potencjalnego dawcy, aby zwiększyć wskaźnik dawstwa narządów, okazuje się przynosić skutki odwrotne do zamierzonych, ponieważ zaufanie do systemu zdrowotnego zostaje raczej osłabione niż wzmocnione ${ }^{58}$ — prof. dr Winfried Kluth.

5. Każda osoba z niewydolnością narządów znajduje się na granicy życia i musi uporać się z faktem swojej ewentualnej śmierci, w najlepszym wypadku to zaakceptować lub zaprzyjaźnić się z tym. Transplantację można rozumieć jedynie jako możliwość, a nie jako obowiązkową korzyść dla współubezpieczonych i współobywateli. Nie istnieje prawo do organów, najwyżej szansa na prezent. Nie istnieje też żaden moralny obowiązek oddawania organów z zasady „chrześcijańskiego obowiązku kochania bliźniego", nie mamy też niepodważalnego prawa dostępu do medycyny. Dlatego należy uczynić wszystko, aby promować gotowość ludzi do dawstwa organów, jednocześnie dając im możliwość podjęcia pozytywnej lub negatywnej decyzji ${ }^{59}$ — Hans Martin Wirth ${ }^{60}$, wspólna opina Kościołów katolickiego i ewangelickiego ${ }^{61}$.

\subsection{OCENA}

Interesujące jest, że liczba powołanych ekspertów przez zwolenników systemu opt out i systemu opt in była podobna, gdyż zastosowano tu wspomniany wcześniej model Hare/Niemeyer ${ }^{62}$. Mimo równego podziału większość ekspertów opowiadała się za modelem opt out (12:6). Najwyraźniej w opiniach dotyczących kwestii sumienia nie można liczyć na odpowiednią politycznie odpowiedź.

Z przedstawionej analizy widać również, że wszyscy lekarze wypowiadali się na rzecz modelu opt out, a prawie wszyscy prawnicy — za modelem opt in, sugerując, że model opt out narusza konstytucyjne prawa podstawowe.

57 Zob. opinia, https://www.bundestag.de/resource/blob/658638/e21ee75f803fd051d517faee8ea 2d677/19-14-0095-8-_ESV-Prof-Dr-Peter-Dabrock_Organspende-data.pdf (dostęp: 2.01.2020).

58 Zob. opinia, https://www.bundestag.de/resource/blob/658470/5a4b8665847dc20b4dc840 9a1e551934/19_14_0095-2-_ESV-Prof-Dr-Kluth_Organspende-data.pdf (dostęp: 17.12.2019).

59 Zob. opinia, https://www.bundestag.de/resource/blob/658842/f17d050348a03c8588ef85e6dfe77972/19_14_0095-14-_ESV-Hans-Martin-Wirth_Organspende-data.pdf(dostęp: 17.12.2019).

60 Pastor sam w 2000 roku otrzymał nerkę; założyciel stowarzyszenia samopomocy GIOS organizacji pożytku publicznego do promocji dawstwa organów. Zob. www.gios-organspende.de (dostęp: 17.12.2019).

${ }_{61}$ Zob. opinia, https://www.bundestag.de/resource/blob/658640/c9bc6c8b4ab522989ee1b8bd47a8d543/19-14-0095-9-_Kommissariat-der-deutschen-Bischoefe_Organspende-data.pdf (dostęp: 17.12.2019).

62 Zob. pkt 5. 


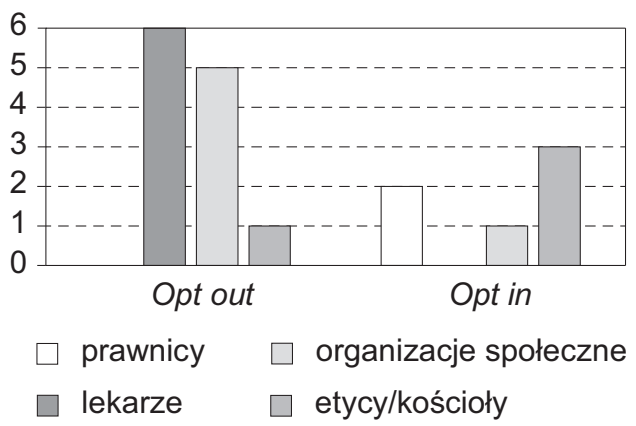

Ilustracja 2. Opinie ekspertów

Źródło: własne opracowanie.

\section{POLITYCZNOŚĆ KOŃCOWYCH GŁOSOWAŃ Z 16 STYCZNIA 2020 ROKU}

Dwa projekty poselskie i jeden wniosek poselski zostały poddane dwugodzinnej debacie podzielonej na 24 mówców po 5 minut każdy. Ustalenie liczby poszczególnych mówców zostało poczynione zgodnie z opisanym już modelem Hare/Niemeyer lub d'Hondt, Sainte-Laguë/Schpers ${ }^{63}$. Po wystąpieniach poszczególnych posłów, zgodnie w tym wypadku z zaostrzonymi zasadami postępowania, następuje głosowanie nad dwoma projektami ustaw i jednym wnioskiem, przy czym w przypadku przyjęcia danego projektu w drugim czytaniu przechodzi się automatycznie do trzeciego czytania przy jednoczesnej rezygnacji z głosowania nad pozostałymi projektami/wnioskami.

Jako pierwszy został poddany pod głosowanie projekt podwójnego sprzeciwu (model opt out), za którym głosowało 292 posłów, przeciwko zaś było 379, trzy osoby wstrzymały się od głosu (z 674 oddanych głosów). Jako drugi przyjęto do głosowania projekt wzmocnienia gotowości do dawstwa organów (model opt in), za którym opowiedziało się 382 posłów, przeciwko było 261, a 28 wstrzymało się od głosu. Tym samym tylko projekt opt in przeszedł do trzeciego głosowania, w którym ostatecznie został przyjęty 432 głosami za, przy 200 przeciw i 37 wstrzymującymi się ${ }^{64}$. Co ciekawe, przeprowadzony przez telewizję ZDF w tym samym dniu sondaż wśród obywateli dawał zwycięstwo modelowi opt out z dużą przewagą $61 \% \mathrm{w}$ stosunku do $36 \%{ }^{65}$.

63 Zob. pkt 6.

${ }^{64}$ Deutscher Bundestag, 140 posiedzenie; protokół z posiedzenia — Plenarprotokoll 19/140, http://dipbt.bundestag.de/dip21/btp/19/19140.pdf (dostęp: 22.01.2020).

${ }^{65}$ Zob. https://www.zdf.de/politik/politbarometer/200116-gruene-erfolgreich-richtung-mitte-100.html (dostęp: 22.01.2020). 


\title{
PODSUMOWANIE
}

W omówionym przypadku klasyczna forma rozumienia suwerena jako najsilniejszej partii nie ma miejsca. W sytuacji odnoszącej się do decyzji sumienia nie jest możliwe uzyskanie kompromisu wewnątrzpartyjnego (lub jest to bardzo trudne). Na podstawie przeprowadzonej analizy można wysunąć tezę, że w przypadku prawa wkraczającego w światopogląd społeczeństwa klasycznie rozumiana polityczność prawa staje przed pewnym ograniczeniem. Frakcje polityczne nie chcą bądź nie mogą zobowiązać swoich członków do utrzymania dyscypliny partyjnej. W tym wypadku jedyną możliwością na przeprowadzenie zmian, które zdaniem partii rządzącej są konieczne, a jednocześnie zmieniają dotychczasowy światopogląd, są projekty poselskie uwzględniające poszczególne poglądy osobiste posłów. Należy jednak zauważyć, że odpolitycznienie tej procedury jest zagrożone sporym ryzykiem, że pożądana reforma może zakończyć się fiaskiem. To właśnie miało miejsce w wypadku projektu podwójnego sprzeciwu ministra J. Spana. Podobne procedury stosowane są $\mathrm{w}$ Niemczech $\mathrm{w}$ innych regulacjach dotyczących sumienia, na przykład na temat aborcji czy eutanazji ${ }^{66}$.

\section{ANALYSIS OF THE LATEST CHANGES \\ IN GERMAN TRANSPLANT LAW - POLITICAL ASPECTS OF CONSCIENCE DECISIONS}

\begin{abstract}
Summary
Law is entangled in politics and its shape largely depends not only on the existing needs of regulation, but also on what vision of values is represented by the legislature in power. The following article presents the current situation in German health policy, where by changing the set of norms of transplant law it is proposed to change the whole system of perception of the human body. In this case, the project introducing the new law is not a project of the ruling coalition, but we are dealing mainly with two competing cross-party projects. When the law project proposes a change in the axiology which needs a conscientiously-dependent decision the political aspect of the law takes a different form from the average, or disappears altogether. The following article will present the political aspects of the new transplant law project in Germany. The article focuses primarily on the dynamic aspect of the politicization of law - that is, on the legislative process and the participation of experts in it, as well as on the epistemological aspect — that is, what kind and scope of research materials were used in the process of politicization of law.
\end{abstract}

Keywords: transplantation law, conscience decisions, organ donation, opt in, opt out

${ }^{66}$ Decyzja sumienia (Gewissenentscheidung) w rozumieniu art. 4 ust. 1 GG; por. orzeczenie BVerfGE 12, 45 (55). 


\section{BIBLIOGRAFIA}

Kelle F., Wiederspruchlösung und Menschenwürde, eine verfassungsrechtliche Untersuchung zur Begründbarkeit einer Organspendepflicht und zur Vereinbarkeit von Menschenwürde und Wiederspruchlösung unter Berücksichtigung ethischer und medizinischer Aspekte, „Schriftenreihe Medizin-Ethik-Recht" 31, 2011, s. 2-46.

Kluth W., Sander B., Verfassungsrechtliche Aspekte einer Organspendepflicht, „Deutsches Verwaltungsblatt" 1997, s. 1285-1293.

Mitre C., Mitre I., Diagnosing “brain death” in intensive care, „The Journal of Critical Care Medicine (Targu Mures)" 2017, nr 3 (3), s. 128-130, doi: 10.1515/jccm-2017-0016.

Nowak P.G., Problemy etyczne transplantologii. Perspektywa niedoboru narzadów do przeszczepów, „Diametros” 42, 2014, s. 150-177, doi: 10.13153/diam.42.2014.686.

Paździora M., Stambulski M., Co może dać nauce prawa polityczność? Przyczynek do przyszłych badań, „Archiwum Filozofii Prawa i Filozofii Społecznej” 2014, nr 1, s. 55-66.

Rithalia A., McDaid C., Suekarran S., Myers L., Sowden A., Impact of presumed consent for organ donation on donation rates: a systematic review, „The BMJ” 2009, $\mathrm{nr} 338$, s. 3162-168.

Siminoff L., Gordon N., Hewlett J., Arnold R.M., Factors influencing families'consent for donation of solid organs for transplantation, ,Journal of the American Medical Association ”286, 2001, nr 1, s. 72-77.

Thaler R.H., Sunstein C.R., Nudge: Improving Decisions About Health, Wealth and Happiness, London 2008.

Weber M., Polityka jako zawód i powołanie, Kraków 1998.

Wróbel J., Zgoda domniemana w polskiej ustawie transplantacyjnej. Watpliwości i obawy natury etycznej, [w:] Etyczne aspekty transplantacji narządów, red. A. Marcol, Opole 1996, s. $36-$ 40.

Zajadło J., Prawoznawstwo - polityczność nauki czy nauka polityczności?, „Przegląd Prawa i Administracji” 110, 2017, s. 41-48. 